\title{
Diskursus Metodologi Studi Hadis Kontemporer Analisa Komparatif antara Pendekatan Tradisional dan Pendekatan Revisionis
}

\begin{abstract}
Ali Masrur ${ }^{1}$
Abstract:

Hadith studies in contemporary period developed into two different approaches: traditional and revisionist approach. Fuat Sezgin, Nabia Abbott, and M.M Azami were the students of Hadith using traditional approach. In studying Hadith, they departed from Islamic basic assumption and scientific method, especially the method of Hadith and rijal sciences. In their works, they never criticized Islamic sources. They believed in what was said, transmitted, interpreted, and written by early muslim generation as what really happened. On the contrary, Ignaz Goldziher, Joseph Schacht, and G.H.A. Juynboll were the students of Hadith using revisionist approach who always see Islamic sources critically and sceptically. They didn't believe in the authenticity of the Islamic sources before they proved that the authenticity of the sources was verified by applying a source critical method. The use of a source critical method was to be special characteristic of revisionist approach in studying the prophetic Hadith.
\end{abstract}

Keywords: Tradisional, revisionis, source critical method

\section{Pendahuluan}

Sebagian besar umat Islam, untuk tidak mengatakan seluruhnya, dengan penuh kepastian menganggap bahwa jika sebuah hadis tertentu dapat ditemukan dalam kitab kanonik (al-kutub al-sittah), lebih-lebih dalam kitab Sahihayn: Sahịh al-Bukhärī dan Sahih Muslim, maka tidak dapat diragukan lagi bahwa hadis itu bersumber atau berasal dari Nabi Muhammad saw. dan dengan demikian tidak lagi memerlukan analisis historis untuk menentukan asalusulnya. Anggapan semacam ini bukan hanya dianut oleh umat Islam, tetapi juga oleh para pengkaji hadis serius seperti Fuat Sezgin, Nabia Abbott, dan

${ }^{1}$ Dosen Fakultas Ushuluddin dan Pascasarjana UIN Sunan Gunung Djati Bandung. E-mail: alimasrur@yahoo.com 
M.M. Azami. ${ }^{2}$ Mereka ini berpendapat bahwa pertumbuhan literatur hadis abad ketiga bukan merupakan akibat dari permalsuan hadis secara besar-besaran, tetapi karena perkembangan jalur isnād itu sendiri. Di samping itu, proses penulisan hadis sebenarnya telah dimulai pada masa hidup nabi dan terus berlanjut dengan cara yang muttasil hingga munculnya berbagai koleksi hadis pada abad ketiga/kesembilan.

Namun berdasarkan temuan-temuan mutakhir di bidang hadis oleh Ignaz Golziher dan Joseph Schacht yang didukung oleh G.H.A. Juynboll, sebuah hadis yang terdapat dalam literatur hadis kanonik tidak dengan sendirinya menjamin kesejahteraan penisbatannya kepada nabi saw. ${ }^{3}$ Jika pendapat pertama dibandingkan dengan pendapat kedua, maka dengan jelas akan terlihat betapa besar perbedaan antara keduanya. Perbedaan hasil temuan mereka itu pada gilirannya mendorong tulisan ini untuk menelusuri akar-akarnya melalui pendekatan tersebut terhadap sumber dan keaslian hadis.

\section{Pendekatan Tradisional dan Pendekatan Revisionis}

Studi Barat tentang sejarah Islam awal, tentang agama, dan tentang kedudukan Alquran, menurut J. Koren dan Y.D. Nevo, telah berkembang menjadi dua Pendekatan yang berbeda. Pendekatan pertama yang dinamakan pendekatan "tradisional" membatasi bidang penelitiannya pada sumber-sumber Islam dan mengujinya dengan cara yang sesuai dengan berbagai asumsi dan tradisi keilmuan Islam. Sedangkan pendekatan kedua yang disebutnya sebagai pendekatan "revisionist" dalam menganalisa berbagai literatur Islam menggunakan metode kritik sumber (source-critical methods) dan juga menjadikan literatur non-Arab kontemporer, temuan-temuan arkeologi, epigrafi, dan numismatik sebagai bukti sejarah yang pada umumnya tidak dikaji oleh aliran tradisional. ${ }^{4}$

${ }^{2}$ Untuk mengetahui ide-ide para peneliti hadis ini secara ringkas, lihat David S. Powers, Studies in Qur'an and Hadith: The Formation of the Islamic Law of Inheritance (Los Angeles: University of California Press, 1986), 4-6.

3 ... the occurrence of a certain tradition ascribed to the prophet in a canonical collection does not automatically entail that that ascription is historically founded. G.H.A. Juynboll, 'Some Isnād - Analytical Method Illustrated on the Basis of Several Woman - Demeaning Sayings from Hadith Literature", dalam Studies on the Origins and Uses of Islamic Hadith (Brookfield, VT USA Variorum Ahgate, 1996), 343.

${ }^{4}$ Penyebutan "revisionist" yang tidak disukai oleh Koren dan Nevo, lebih disebabkan oleh kesimpulan yang dicapai daripada metode yang dipakai. Lihat J. Koren and Y.D. Nevo, "Methodological Approaches to Islamic Studies," dalam Der Islam 68 (1991), 87. Pendekatan ini dinamakan revisionis karena berangkat dari asumsi bahwa kesimpulan dari pendekatan tradisional memerlukan revisi. Yusuf Rahman, "A Modern 
Studi hadis yang termasuk dalam studi sejarah Islam awal tentu saja tidak perlu dikecualikan dari sudut pandang ini. Fuat Sezgin, Nabia Abbott, dan M.M. Azami adalah para peneliti hadis aliran tradisional yang dalam mengkaji hadis mereka berangkat dari asumsi dasar maupun metode keilmuan Islam, khususnya metode ilmu hadis sendiri. Dalam berbagai karya mereka, mereka bisa dikatakan tidak pernah mengkritik sumber-sumber Islam. Para peneliti tersebut begiru saja mempercayai apa yang dikatakan, diriwayatkan, ditafsirkan, dan ditulis oleh generasi Islam awal. Sebaliknya, Ignaz Goldziher, Joseph Schacht, dan G.H.A. Juynboll adalah kelompok revisionis yang selalu memandang sumber-sumber dari kalangan Islam dengan daya kritis dan skeptis yang begitu tinggi. Mereka tidak begitu saja mempercayai keautentikannya sebelum terbukti bahwa sumber itu benar-benar teruji dengan metode kritik sumber. Jadi, penggunaan metode kritik sumber menjadi ciri khas aliran revisionis untuk mengkaji hadis.

Dasar metodologi revisionis dengan lebih jelas dapat dilihat dalam ide-ide John Wansbrough yang menyatakan bahwa sumber-sumber tertulis, apapun sumber tertulis itu termasuk juga sumber-sumber muslim, tidak dapat bercerita kepada kita tentang "what really happened", tetapi hanya menggambarkan apa yang dianggap atau dipikirkan oleh penulis sumber itu sebagai peristiwa yang telah terjadi. Mengapa Wansbrough tidak percaya kepada sumber-sumber muslim? Karena menurutnya, seluruh karya tentang dokumentasi Islam awal hanya merupakan "salvation history". Salvation history bukan merupakan uraian-uraian historis dari berbagai peristiwa yang terbuka untuk dikaji oleh sejarawan karena salvation history tidak pernah terjadi. ${ }^{5}$ Kalau demikian, lalu apakah sejarah aktual dalam pengertian "what really happened" itu dapat diketahui? Sebenarnya sejarah aktual itu telah terserap dalam penafsiran belakangan dan tidak dapat dipisahkan darinya. Jika sudah terserap, apakah dengan begitu masih terdapat "kernel of history" atau inti kebenaran sejarah. Dan jika ada, apakah mungkin "kernel" itu diidentifikasi dan dikeluarkan dari rekaman sejarawan tersebut? Dalam hal ini, Wansbrough mengatakan, "Tidak", karena rekaman yang kita miliki, menurutnya, merupakan rekaman eksistensial dari pemikiran dan keimanan gerenerasi selanjutnya, yakni generasi setelah peristiwa aktual. ${ }^{6}$ Memang ide-ide Wansbrough rasanya terlalu tajam seolah-

Western Approach to the Qur'an: A Study of John Wansbrough's Qur'anic Studies and Its Muslim Replies," dalam McGill Journal of Middle East Studies, vol.4 (1996), 137.

${ }^{5}$ Andrew Rippin, "Literary Analysis of Qur'àn, Tafsìr, and Sira: The Methodologies of John Wansbrough," dalam Richard C. Martin (ed.), Approaches to Islam in Religious Studies (Tucson, Arizona: The University of Arizona Press, 1985), 154-155. Lihat juga J. Koren and Y.D. Nevo, "Methodological Approaches," 89.

${ }^{6}$ Rippin, "Literary Analysis," 156. 
olah rekaman-rekaman sejarah itu tidak bisa menggambarkan peristiwa sebenarnya dan dengan demikian terdapat diskontinuitas antara peristiwa dan rekamannya. Hal ini juga tampak pada kajian hadis kontemporer.

Joseph Schacht, misalnya, mengadopsi metode kritik sumber tersebut dan mengembangkannya menjadi tiga teori yang brilian: teori backward-projection, e silentio, dan common link. Teori backward-projection mengatakan bahwa hadis itu pada awalnya merupakan doktrin-doktrin aliran-aliran fikih klasik, seperti Ibrāhīm al-Nakhā'i, lalu kepada autoritas yang lebih tinggi di kalangan sahabat seperti Ibnu Mas'ūd, dan akhirnya kepada nabi saw. ${ }^{7}$ Teori ini tentu saja sangat terkait dengan teori selanjutnya, yakni teori e silentio yang mengatakan bahwa cara pembuktian bahwa suatu hadis tidak ada pada masa tertentu adalah dengan cara menunjukkan bahwa hadis tidak ada pada masa tertentu adalah dengan cara menunjukkan bahwa hadis tersebut tidak dipakai sebagai sebagai dalil dalam diskusi hukum yang merupakan sebuah keharusan jika hadis itu ada. ${ }^{8}$ Sementara teori common link yang belakangan ini dikembangkan oleh G.H. A. Juynboll adalah teori yang membicarakan para periwayat yang menjadi titik temu dan sekaligus bertanggung jawab atas penyebaran hadis. Menurutnya sebagian besar common link adalah para tabiin dan tabiit tabiin. Jarang, sekali tabiin besar dan hampir tidak pernah seorang sahabat menjadi common link. ${ }^{9}$ Teori-teori ini pada dasarnya merupakan penjabaran dan pemekaran dari metode kritik sumber yang mestinya berangkat dari asumsi bahwa sumber-sumber Islam, termasuk hadis, tidak bisa begitu saja dipercaya sebelum menelusuri keasliannya.

Dari perspektif tersebut, G.H.A. Juynboll mengkritik keras karya-karya Sezgin, Abbott, dan Azamī dengan mengatakan bahwa mereka kelihatannya tidak menyadari bahwa sebuah naskah yang dianggap klasik sekalipun dapat saja dipalsukan dengan mudah oleh orang-orang tertentu, seperti dalam katakatanya sendiri berikut ini:

Something will always struck me in the work of Sezgin, Azmi and also in that of Abbott - to which I shall turn in a moment - is that they do not

\footnotetext{
${ }^{7}$ Joseph Schacht, An Introduction to Islamic Law (Oxford: Claredon Press, 1964), 16-35.

${ }^{8}$ Joseph Schacht, The Oigins of Muhammadan Jurisprudence (Oxford: Clarendon Press, 1950), 140. Ia mengatakan, "The best way of proving taht a tradition did not exist at at certain time is to show that it was not used as a legal argument in a discustion which would have made reference to it imperative, if it had existed."

${ }^{9}$ G.H.A. Juynboll, "Some Notes on Islam's First Fuqahā' Distilled from Early Hadith Literature," dalam Studies on the Origins and Uses of Islamic Hadith, 292.
} 
seem to realize that, even if a manuscript or a papyrus is unearthed with an allegedly ancient texts, this text could very easily have been forged by an authority who lived at a time later that the supposedly oldest an authority goven in its isnād. Isnäd fabricarion occurred, as everi body is bound to agree, on just as vast a scale as matn fabrication. ${ }^{10}$

(Sesuatu hal yang selalu mengejutkan saya dalam karya Sezgin, Azmi, dan juga karya Abbott - padanya saya merujuk sewaktu-waktu - adalah mereka kelihatannya tidak mengakui bahwa, bahkan jika sebuah naskah atau papirus itu ditemukan dengan penggalian berbagai naskah yang dianggap klasik, naskah ini telah dipalsukan dengan sangat mudah oleh otoritas yang hidp pada saat yang lebih belakangan daripada otoritas yang dianggap tertua yang terdapat dalam isnād. Pemalsuan isnād tejadi, sebagaimana setiap orang, pasti setuju, tepatnya seluas skala pemalsuan matan).

Kritik G.H.A. Juynboll terhadap keaslian sumber-sumber Islam sebenarnya bukan sesuatu hal yang baru dalam kajian Islam. Hal ini telah didengungkan jauh sebelumnya oleh Ignaz Goldziher dan Joseph Schacht yang memahami bahwa berbagai pendekatan yang disandarkan kepada Muhammad saw. dan dipakai untuk mendukung posisi hukum dan doktrin yang ada dalam Islam secara aktual berasal dari "periode yang relatif lebih belakangan" dari saat ketika posisi hukum dan doktrin ini sedang mencari dukungan kepada sunnah.

Berbeda dengan kalangan revisionis, aliran tradisional cenderung menekankan otentisitas sumber-sumber Islam dan menerimanya secara taken for granted bagi penyelidikan selanjutnya sehingga tentu saja hasil temuan mereka tidak bisa keluar dari asumsi-asumsi dasar dalam lmu hadis. Pernyataan Abbott bahwa koleksi hadis telah dimulai pada masa nabi oleh para anggota keluarga, klien dan sahabat dekatnya dan diriwayatkan kepada generasi berikutnya hingga era kitab-kitab kanonik yang terkenal itu ${ }^{11}$ dapat dijadikan sebagai bukti bagi kecenderungan semacam ini.

${ }^{10}$ Juynboll, Muslim Tradition: Studies in Chronology, Provenance and Authorship of Early Hadith (Cambridge: Cambridge Univesity Press, 1983), 4.

${ }^{11}$ Collection of Hadith was begun in Muhammad life time by members of his family, clients, and close companions. Nabia Abbott, "Hadith Literature, Collection and Transmission of Hadith," dalam A.F.L. Beeston and Others (eds.) Arabic Literature to the End of Umayyad Period (Cambridge: Cambridge University Press, 1983), 289-298. Lihat juga, Nabia Abbott, Studies in Arabic Literary Papyri, vol. II, Qur'annic Commentary and Tradition (Chicago: The University of Chicago Press, 1967), 2. Dalam buku ini, ia mengatakan, "Analysis of the content and the chains of transmission of the 
Sejalan dengan Abbott, Fuat Sezgin, setelah menguji sejumlah naskah Arab dan menganalisa bentuk-bentuk yang digunakan oleh para periwayat hadis, menjelaskan bahwa pencatatan hadis di kalangan orang-orang muslim telah dimulai lebi awal daripada yang dikatakan oleh Goldziher yang pada gilirannya, kesimpulan Sizgin juga tidak jauh berbeda dengan Abbott sebagaimana telah disinggung di atas. Untuk membuktikannya, Sezgin menganalisa kata kitāb yang merupakan kunci dalam kajiannya. Menurutnya, periwayatan sumber-sumber tertulis, termasuk hadis, telah dimulai sejak masa awal dalam sejarah Islam. Kata kitāb yang seringkali dipakai dalam periwayatan hadis seharusnya tidak dipahami sebagai "mencatat hadis", tetapi sebagai meriwayatkan hadis dengan prosedur tertulis (kitāb, kitābah, mukātabah), yaitu cara periwayatan yang bergantung pada bahan-bahan tertulis dari syeikh. ${ }^{12}$ Dengan demikian, literatur hadis yang ada sekarang ini tidak perlu disangsikan kesahihannya karena pencatatan hadis sudah dimuali sejak awal.

Pandangan Azmi terhadap sumber-sumber hadis tentu saja tidak berbeda dengan pandangan para pendahulunya. Dalam Studies in Early Hadith Literature, ia menekankan bahwa mengkaji hadis harus melalui literatur hadis dan bukan melali buku-buku fikih atau sirah. Menurutnya, buku-buku fikih ataupun sirah tidak memadai untuk dipakai sebagai sumber bagi studi hadis, isnād dan perkembangannya. Adalah salah total, bahkan bisa dikatakan tidak ilmiah, bila mengkaji hadis dari buku-buku fikih seperti yang dilakukan Schach. Oleh sebab itu, kesimpulan apapun yang dicapai tentang hadis, periwayatannya, sistem isnād dan lain sebagainya yang berdasarkan kajian hukum, akan salah dan tidak dapat dipercaya. ${ }^{13}$

traditions of the documents and of their available parallels in the standard collections, supplemented by the result of an intensive sudy of the source on the sciences of tradition, 'ülum al-Hadith, lead me to conclude that oral and written transmission went hand in hand almost from the start, that the traditions of Muhammad as transmitted by his companions and their succeccors were, as a rule, scrupulously scrutinized at each step of the transmission, and that the so-called phenomenal growth of tradition in the second and the third centuries of Islam was not primarily growth of the content, so far as the Hadith of Muhammad and the Hadith of the companions are concerned, but represents largely the progressive increase of parallel and multiple chains of transmission."

${ }^{12} \mathrm{Akh}$. Minhaji, "Joseph Schacht's Contribution to the Study of Islamic Law" (M.A. Thesis at Institute of Islamic Studies McGill University, 1992), 45-46. Tesis Akh. Minhaji ini telah diterjemahkan oleh penulis dengan judul Kontroversi Pembentukan Hukum Islam Kontribusi Joseph Schacht (Yogyakarta, UII Press, 2001).

${ }^{13}$ The literature of legal science or the Sira work is unadequate for the study of the traditions and isnäds and their 'growth'... It is totally wrong, even unscientific, to study Hadith as a subject in the legal books. Therefore, any conclusion about traditions, their transmissions, or the isnäds system, etc., based on the study of legal literature would be 
Pernyataan Azami ini menunjukkan dengan jelas betapa ia terlalu percaya terhadap literatur hadis yang menurut kalangan revisionis dipandang mengundang banyak hadis-hadis lemah dan bahkan mawḍ $\bar{u}^{\prime}$. Bahkan dalam kesempatan yang lain, Azami mengatakan bahwa tidak ada alasan untuk menolak sistem isnād. Karena telah terbukti bahwa sistem isnād itu mengandung unsur-unsur yang patut diterima seara keseluruhan. ${ }^{14}$

Studi hadis yang termasuk dalam studi sejarah Islam awal tentu saja tidak perlu dikecualikan dari sudut pandang ini. Fuat Sezgin, Nabia Abbott, dan M.M. Azami adalah pra peneliti hadis aliran tradisional yang dalam mengkaji hadis mereka berangkat dari asumsi dasar maupun metode keilmuan Islam, khususnya metode ilmu hadis sendiri. Dalam berbagai karya mereka, mereka bisa dikatakan tidak pernah mengkritik sumber-sumber Islam. Para peneliti tersebut begiru saja mempercayai apa yang dikatakan, diriwayatkan, ditafsirkan, dan ditulis oleh generasi Islam awal. Sebaliknya, Ignaz Goldziher, Joseph Schacht, dan G.H.A. Juynboll adalah kelompok revisionis yang selalu memandang sumber-sumber dari kalangan Islam dengan daya kritis dan skeptis yang begitu tinggi. Mereka tidak begitu saja mempercayai keautentikannya sebelum terbukti bahwa sumber itu benar-benar teruji dengan metode kritik sumber. Jadi, penggunaan metode kritik sumber menjadi iri khas aliran revisionis untuk mengkaji hadis.

Tidak berlebihan jika Coulson mengatakan,

At the same time it must, of course, be frankly recognized that the Muslim and the Western methods of Hadith criticim are irreconcilable because they rest upon totally different premisses. Between the dictate of religious faith on the one hand and secular historical criticism on the other, there can be no middle way of true objectivity. ${ }^{15}$

(Pada saat yang sama, tentu harus diakui secara terus terang bahwa metode kritik hadis kalangan Muslim dan Barat tidak dapat didamaikan karena metode mereka itu berpijak pada asumsi-asumsi yang berbeda secar total. Antara perintah keimanan keagamaan, di satu sisi, dan kritik historis sekuler di sisi yang lain, tidak dapat ada jalan tengah bagi objektivitas yang benar).

faulty and unreliable, M.M. Azami, Studies in Early Hadith Literature with A Critical Edition of Some Early Texts (Beirut: al-Maktab al-Islami, 1968), 222.

${ }^{14}$ Azami, Studies in Early Hadith Literature, 247.

${ }^{15}$ Noel J. Coulson, "European Criticism of Hadith Literature," dalam A.F.I. Boeston and Others (eds.), Arabic Literature to the End of the Umayyad Period (Cambridge: Cambridge University Press, 1983), 321. 


\section{Implikasi terhadap Sumber dan Keaslian Hadis}

Sebuah pendekatan, paradigma atau perspektif yang berbeda tentu dapat akhirnya menghasilkan temua yang berbeda pula. Jika pendekatan tradisional tetap saja menegaskan kesahihan literatur hadis dan menganggapnya benarbenar bersumber dari nabi, sebaliknya pendekatan revisionis dengan caranya sendiri mencoba merevisi kesimpulan itu dengan menyatakan bahwa kesahihan hadis perlu diragukan karena berdasarkan kajian mereka, hadis-hadis yangdiklain berasal dari nabi itu ternyata tidak terbukti secara historis. Pada dasarnya, hadis-hadis itu memang berasal dari periode Islam awal, yakni generasi sahabat, tabiin, dan tabiit tabiin, tetapi tidak sampai kepada nabi. Lebih jauh lagi, hadis-hadis itu bahkan diklaim sebagai hasil gerakan pemalsuan dalam skala besar yang pernah terjadi dalam sejarah periwayatan hadis. Untuk lebih detailnya, marilah kita lhat uraian berikut ini.

Ignaz Goldziher, yang sedikit telah disinggung di atas, mengemukakan bahwa fenomena hadis memang berasal dari zaman Islam yang paling awal. Namun karena kandungan hadis yang terus membengkak pada era selanjutnya dan dalam setiap generasi muslin materi hadis itu berjalan pararel dan doktrindoktrin fikih dan teologi yang seringkali saling bertentangan, maka ia menyimpulkan bahwa sangat sulit menentukan hadis-hadis yang orisinal dari nabi. ${ }^{16}$ Sebagian materi hadis yang terdapat dalam koleksi hadis itu, menurutnya, merupakan hasi perkembangan keagamaan, historis, dan sosial Islam dua abad pertama atau refleksi dari berbagai kecenderungan yang tampak pada masyarakat muslim selama masa-masa tersebut. ${ }^{17}$ Sebagai akibatnya, produk-produk kompilasi hadis yang ada dewasa ini tidak dapat dipercaya secara keseluruhannya sebagai sumber ajaran dan perilaku nabi sendiri. ${ }^{18}$

Gagasan Joseph Schacht tentang keaslian dan sumber hadis lebih tegas daripada pendapat Goldziher. Dalam The Origins, ia mengatakan bahwa isnād memiliki kecenderungan untuk diproyeksikan ke belakang. Menurutnya, isnād berawal dari bentuk yang sederhana, lalu diperbaiki sedemikian rupa dengan cara mengaitkan doktrin-doktrin aliran fikih klasik kepada tokoh yang lebih

${ }^{16}$ Ignaz Goldziher, Muslim Studies, vol, 2, trans. C.R. Barber and S.M. Stern (London: George Allen \& Unwin LTD, 1971), bab II dan seterusnya.

${ }^{17}$ We.... will probably consider by far the greater part of it as the result of the religious, historical and social development of Islam during the first two centuries... The Hadith will not serve as a document for the history of the infancy of Islam, but rather as a reflection of the tendencies which appeared in the community during the maturer stages of its development. See Goldziher, Muslim Studies, 19.

${ }^{18}$ Fazlur Rahman, Islam, terj. Ahsin Mohammad (Bandung: Pustaka, 1994), 52-53. 
awal seperti sahabat dan akhirnya kepada nabi. ${ }^{19}$ Perbaikan isnād ini tentu saja paralel dengan perbaikan dan perkembangan matan hadis. Karena isnād dan matan hadis merupakan rekayasa sebgai hasil dari pertentangan antara aliran fikih klasik dan alhi hadis, maka tak satu pun hadis nabi, lebih-lebih yang terkait dengan persoalan hukum, dapat dianggap sebagai hadis sahih. ${ }^{20}$ Dengan kata lain, hadis-hadis itu sebenarnya tidak bersumber dari nabi, tetapi dari periode yang relatif belakangan.

G.H.A. Junboll yang banyak mengadopsi teori-teori Schacht, terutama common link mengemukakan bahwa teori common link adalah teori yang brilian. Ayangnya, teori ini belum dikembangkan dalam skala yang lebih luas, bahkan oleh Schacht sendiri. ${ }^{21}$ Common link adalah istilah yang dipakai untuk seorang periwayat yang mendengar sesuatu dari (jarang lebih dari) seorang yang berwenang lalu menyebarkannya kepada sejumlah murid yang pada gilirannya keanyakan dari merka menyebarkan lagi kepada dua atau lebih muridnya. Dengan kata lain common link aalah periwayat tertua yang disebut dalam berkas isnād itu mulai menyebar pertama kali, maka di sanalah ditemukan common link-nya. Teori ini berangkat dari asumsi dasar bahwa makin banyak garis periwayatan yang bertemu atau meninggalkan periwayat tertentu, makin besar pula momen periwayatan itu memiliki klain kesejarahan. Sebaliknya jika suatu hadis dikatakan diriwayatkan dari nabi melali seseoran, yakni seorang sahabat, kepada orang lain, yakni seorang tabiin (kepada orang lain, yaitu tabiin lain) yang pada akhirnya tiba pada common link (kaitan bersama), dan setelah itu jalur isnād bercabang keluar, maka kesejarahan jalur periwayatan itu tidak bisa dipertahankan. Dalam kenyataan, sebagian besar isnād yang mendukung bagian yang sama dari satu matan hanya mulai bercabang dari kaitan bersama, yaitu sorang periwayat yang berasal dari generasi kedua atau ketiga sesudah nabi. ${ }^{22}$

Yang sering terjadi adalah bahwa kaitan bersama sebuah hadis adalah tabiin dan muridnya, tabiit tabiin. Jarang sekali bahkan hampir tidak pernah seorang sahabat menjadi kaitan bersama. Kalau demikian, maka hadis itu sebenarnya tidak berasal, atau setidak-tidaknya secara historis belum terbukti, dari nabi tetapi berasal dan bersumber dari para tabiin dan tabiit tabiin. Hal ini

${ }^{19}$ Joseph Schacht, The Origins, 163, 165. Lihat juga bukunya, An Introduction to Islamic Law, 31-35.

${ }^{20}$ Hardly any of these traditions, as far as matters of religious law are concerned, can be considered authentic. Joseph Scahcht, An Introduction, 34.

${ }^{21}$ Juynboll, Muslim Tradition, 207.

${ }^{22}$ Juynboll, "Some Isnād-Analytical Methods," dalam Studies on the Origin and Uses of Islamic Hadith, 351-353. 
memperkuat idenya tentang kronologi hadis yang menyatakan bahwa hadis yang berakhir pada tabiin lebih tua daripada hadis yang berakhir pada sahabat yang pada gilirannya lebih tua daripada hadis nabi. Secara sederhana dapat dikatakan, makin dalam penyelaman di bawah common link, makin baru asalusul jalur isnād itu dan dengan demikian makin baru asal-usul hadis itu. ${ }^{23}$

Demikianlah kelompok revisionis memandang sumber dan kesahihan hadis. Secara umum, mereka berpendapat bahwa hadis sebenarnya tidak bersumber dari nabi tetapi dari periode sahabat, tabiin dan tabiit tabiin karena hadis merupakan hasil dari perkembangam Islam pada masa pembentukan. Berbeda dengan implikasi yang ditimbulkan ari perspektif revisionis terhadap sumber dan keaslian hadis, kelompok tradisional pada umumnya berpendapat bahwa penisbatan hadis terhadap nabi sebagaimana terdapat dalam kitab koleksi hadis dapat dipertanggung jawabkan. Jika ide-ide Sezgin dan Abbott sedikit banyak telah dibicarakan sebelumnya, maka sekarang saya akan melihat ide-ide Azami tentang persoalan tersebut.

Azami dengan tegas mengkritik perspektif revisionis, khususnya teori backward projection dari Schacht. Contoh-contoh yang diberikan Schacht sebaliknya dapat menolak teorinya sendiri. Fenomena isnād dan banyaknya periwayat yang berasal dari provinsi yang berbeda-beda dengan jelas membuktikan ketidakakuratan teori itu. ${ }^{24}$

Sistem isnād, menurut Azmi, telah dimulai pada masa hidup nabi dan telah dipakai oleh sahabat untuk meriwayatkan hadis. Para sahabat, bahkan pada masa hidup nabi, telah terbiasa meriwayatkan hadis ketika mereka bertem. Lebih jauh, para sahabat dengan sengaja mendatangi nabi untuk mendengar hadisnya dan kemudian menyampaikannya kepada sahabat yang tidak hadir dalam pertemuan tersebut. Dalam meriwayatkan hadis, secara alami mereka menggunakan kata-kata seperti nabi berbuat begini dan begitu atau nabi berkata begini dan begitu. Kata-kata semacam ini merupakan cikal bakal sistem isnād yang tentu saja pada saat itu masih sangat sederhana. ${ }^{25}$

Namun setelah tejadi pergolakan politik pada dekade keempat dalam sejarah Islam, hadis-hadis palsu mulai bermunculan dalam wilayah politik yang dipakai untuk mendukung atau mendiskriditkan partai-partai tertentu. Karena itu, para ahli hadis lebih hati-hati dan mulai mengkritik serta mencari sumber-

${ }^{23}$ Juynboll, "Some Isnād- Analytical Methods," 368-369.

${ }^{24}$ The examples supplied by Schacht tend to refute his own theory. The Phenomena of isnad, the number of transmitters belonging to scores of provinces, make the theory of "projecting back", artificial creations and similiar statements almost impossible to accept. Azami, Studies in Early Hadith Literature, 247.

${ }^{25}$ Azamī, Studies in Early Hadith Literature, 210-213. 
sumber informasi yang dapat dipercaya. Setlah itu, pemakai isnād dipandai semakin penting. Dengan demikian, tidak ada perbaikan apapun dlaam sistem isnād. Kalupun ada, maka hal itu sudah dilakukan pengecekan oleh para ahli hadis. Memang tidak semua isnād itu sahih, tetapi juga tidak semua isnād itu palsu. isnād keluarga seperti isnād Mālik - Nāfi' - Ibnu 'Umar yang dikritik Schacht sebagai isnād palsu tidak perlu diragukan keasliannya. Memang banyak isnād keluarga yang palsu tetapi tidak sedikit pula yang sahih. ${ }^{26}$

Membuktikan bahwa hadis itu otentik atau tidak memang bukan sesuatu yang mudah. Crone, misalnya, mengatakan, untuk tujuan-tujuan praktis adalah tidak mungkin membuktikan keontetikan hadis dan tidak mungkin pula membuktikan ketidakotentikannya. Orang-orang yang mempertahankan otentisitas hadis, yakni kelompok tradisional, berpegang pada asumsi bahwa hadis itu seharusnya dipandang sahih jika kebalikannya tidak dapat dibuktikan, sementara kelompok revisionis berargumen bahwa hadis seharusnya dipandang sebagai tidak otentik jika belum terbukti kebalikannya. Karena pembuktian dari yang sebaliknya itu sangat sulit, maka hasilnya adalah terjadinya benturan tajam antara orang-orang yang menyajikannya sebagai bukti bagi pekembangan Islam belakangan. ${ }^{27}$ Namun, jika kita melihat temuan Juynboll yang mengatakan bahwa sahabat juga terkadang menjadi common link, yang bergantung jawab atas penyebaran hadis, maka bisa saja suatu saat ditemukan hadis-hadis di mana di dalamnya nabi sendiri yang menjadi common link. Dan hal itu sedikit banyak akan mengarahkan hasil temuan kalangan revisionis lebih dekat dengan kesimpulan aliran tradisional.

Namun tidak bisa diingkari bahwa hadis-hadis yang terdapat dalam kitab kanonik, setidak-tidaknya hingga saat ini, sulit dibuktikan secara historis berasal dari nabi. Hanya saja apakah dengan demikian kesulitan itu membuat kita menyimpulkannya sebagai pemalsuan. Penulis sendiri lebih sependapat dengan Fazlur Rahman yang memakai kata "formulation" (perumusan) daripada kata "forgery" atau "concoction" (pemalsuan) karena walaupun hadis itu secara verbal tidak berasal dari nabi, tetapi semangatnya paling tidak berasal darinya karena hadis merupakan penafsiran dan perumusan situasional dari semangat kenabian. ${ }^{28}$ Jika hal ini diakui benar, maka istilah forgery akan salah bila dipakai untuk menggambarkan asal-usul hadis dan justru istilah fomulasi jauh lebih

${ }^{26}$ Azamī, Studies in Early Hadith Literature, 247.

${ }^{27}$ Akh. Minhaji "Joseph Schacht's Contribution," 80-81.

${ }^{28}$ We can not call Hadith a forgery because it reflects the living Sunna and the living Sunna was not a forgery, but a progressive interpretation and formulation of the Prophetic Sunna. Fazlur Rahman, Islamic Methodology in History (Karachi: Central Institute of Islamic Research, 1965), 80. 
tepat. Hadis tidak bisa dikatakan sebagai pemalsuan karena hadis itu sebenarnya merefleksikan apa yang disebut dengan tradisi yang hidup (living tradition), sementara tradisi yang hidup itu bukanlah pemalsuan, tetapi penafsiran dan formulasi progresif dari sunnah nabi.

\section{Kesimpulan}

Demikianlah, dapat melihat dari diskusi tersebut betapa perbedaan perspektif akan menimbulkan konsekwensi dan implikasi yang berbeda pula. Pendekatan tradisional dengan asumsi dan metodenya telah membuktikan kesahihan hadis disertai dengan argumen yang cukup meyakinkan. Sama halnya, perspektif revisionis dengan postulat dan caranya sendiri merevisi kesimpulan aliran tradisional tentang keaslian hadis dan lebih cenderung memandang hadis sebagai produk generasi muslim belakangan. Kedua pendekatan itu tidak hanya berbeda, tetapi sungguh-sungguh berhadapan dan bertentangan satu sama lain. Hal ini disebabkan karena aliran tradisional terlalu percaya pada sumber keislaman sementara kalangan revisionis terlalu skeptis terhadap sumbersumber tersebut. Dalam diskursus keilmuan, perbedaan adalah sesuatu yang sangat wajar dan seringkali merupakan tuntutan ilmiah. Semakin banyak perbedaan pendapat, semakin luas pula cakrawala kita dalam memandang sejarah awal perkembangan hadis.

Dari sudut paradigma yang digunakan saya kira mereka, aliran tradisional dan revisionis, sulit dipertemukan dan memang tidak perlu dipertemukan, tetapi dari hasi temuannya bisa saja kesimpulan kedua aliran itu semakin dekat pada suatu waktu bisa mencapai titik temu. Tetapi yang perlu diperhatikan adalah bahwa meskipun tidak semua hadis itu bersumber dari nabi, saya kita umat Islam tidak perlu merasa risau dan khawatir karena generasi sahabat, tabiin, dan tabiit tabiin adalah generasi yang dapat juga dijadikan referensi dan sumber bagi ajaran Islam dan dengan demikian sumber ajaran Islam pun semakin luas.

\section{Daftar Pustaka}

Abbott, Nabia. Studies in Arabic Literary Papyri, vol. II, Qur'anic Commentary and Tradition. Chicago: The University of Chicago Press, 1967.

Azami, M.M. Studies in Early Hadith Literature with A Critical Edition of Some Early Texts. Beirut: al-Maktab al-Islami, 1968.

Beeston A.F.L. and Others (eds.) Arabic Literature to the End of Umayyad Period. Cambridge: Cambridge University Press, 1983. 
Coulson, Noel J. "European Criticism of Hadith Literature." Dalam A.F.I. Boeston an Others (eds.). Arabic Literature to the End of the Umayyad Periode. Cambridge: Cambridge University Press, 1983.

Goldziher, Ignaz. Muslim Studies. Vol, 2. Trans. C.R. Barber and S.M. Stern. London: George Allen \& Unwin LTD, 1971.

Juynboll, G.H.A. "Some Isnād - Analytical Method Illustrated on the Basis of Several Woman - Demeaning Sayings from Hadith Literature." Dalam Studies on the Origins and Uses of Islamic Hadith. Brookfield, VT USA Variorum Ahgate, 1996.

-------. 'Some Notes on Islam's First Fuqaha', Distilled from Early Hadith Literature." Dalam Studies on the Origin and Uses of Islamic Hadith. Brookfield, VT USA Variorum Ahgate, 1996.

-------. Muslim Tradition: Studies in Chronology, Provenance and Authorship of Early Hadith. Cambridge: Cambridge Univesity Press, 1983.

Koren, J. and Nevo, Y.D. "Methodological Approaches to Islamic Studies." Dalam Der Islam 68 (1991).

Minhaji. Akh. Kontroversi Pembentukan Hukum Islam: Kontribusi Joseph Schacht. Yogyakarta, UII Press, 2001.

Powers, David S. Studies in Qur'an and Hadith The Formation of the Islamic Law of Inheritance. Los Angles: Univercity of California Press, 1986.

Rahman, Fazlur. Islam. Terj. Ahsin Mohammad. Bandung: Pustaka, 1994.

-------. Islamic Methodology in History. Karachi: Central Institute of Islamic Research, 1965.

Rahman, Yusuf. "A Modern Western Approach to the Qur'ān: A Study of John Wansbrough's Qur'ānic Studies and Its Muslim Replies. Dalam McGill Journal of Middle East Studies, vol. 4 (1996).

Rippin, Andrew. "Literary Analysis of Qur'ān, Tafsìr, and Sirra: The Methodologies of John Wansbrough." dalam Richard C. Martin (ed.). Approaches to Islam in Religious Studies. Tucson, Arizona: The University of Arizona Press, 1985.

Schacht, Joseph. An Introduction to Islamic Law. Oxford: Claredon Press, 1964.

-------. The Origins of Muhammadan Jurisprudence. Oxford: Clarendon Press, 1950. 